$x-34$ n 20

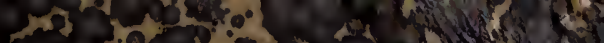

of

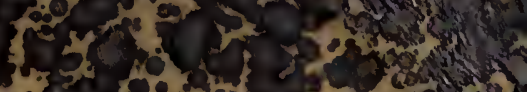

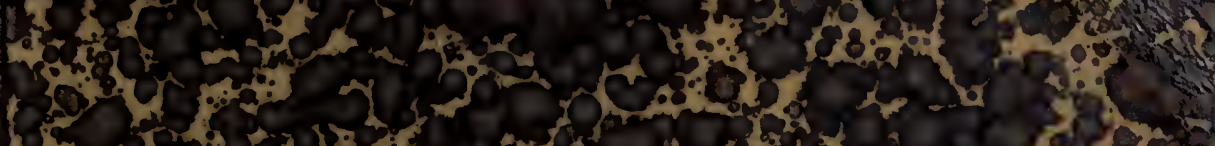

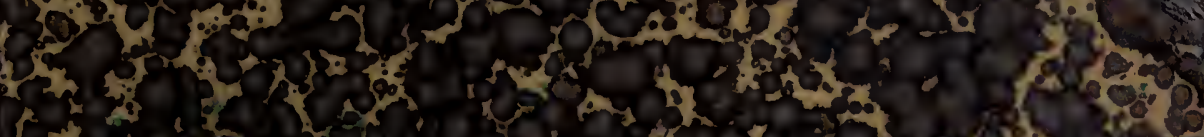

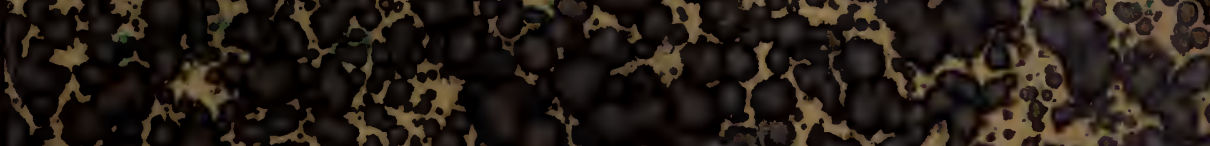

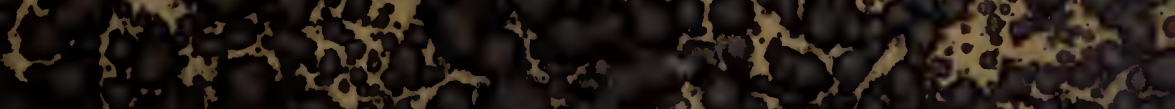

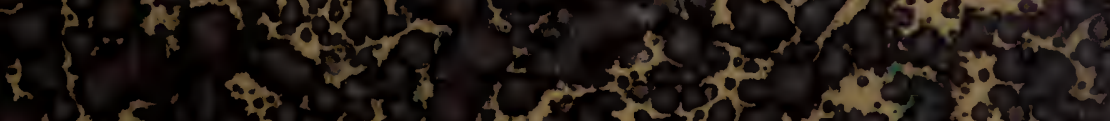

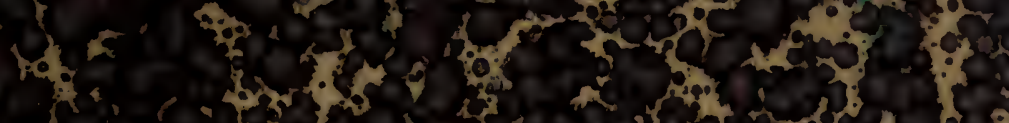

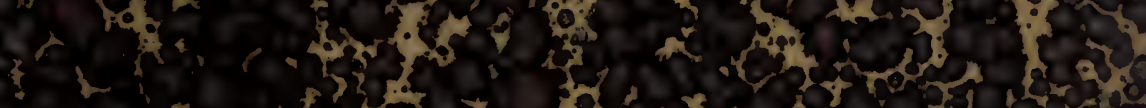

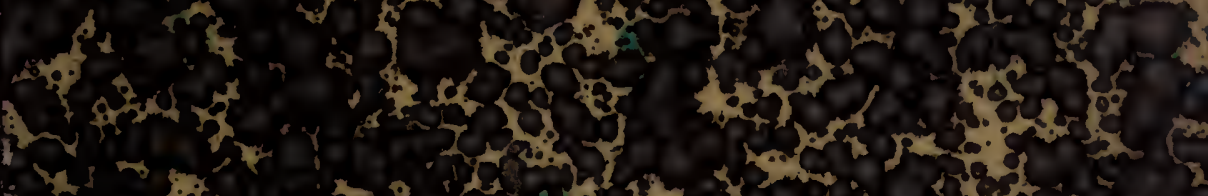

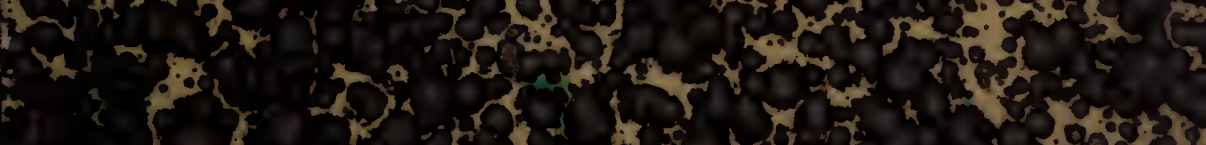

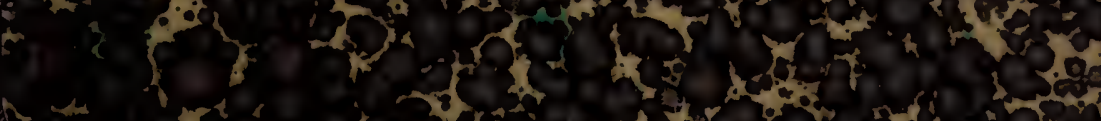

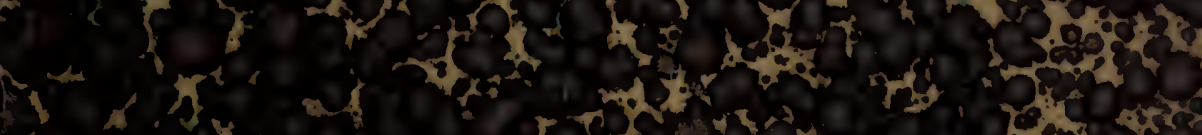

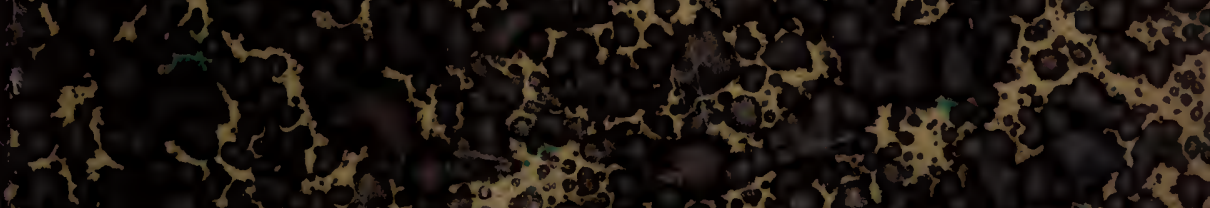

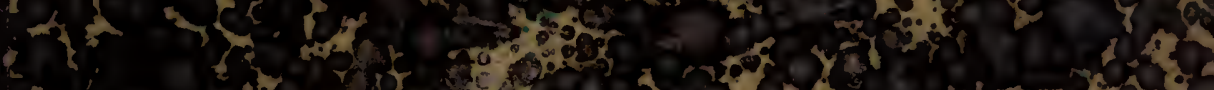
a

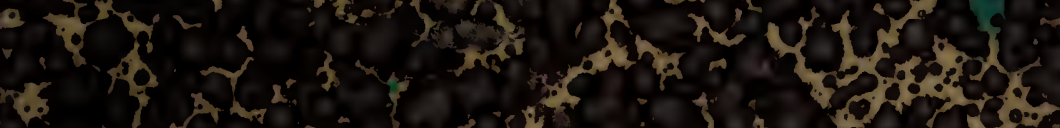

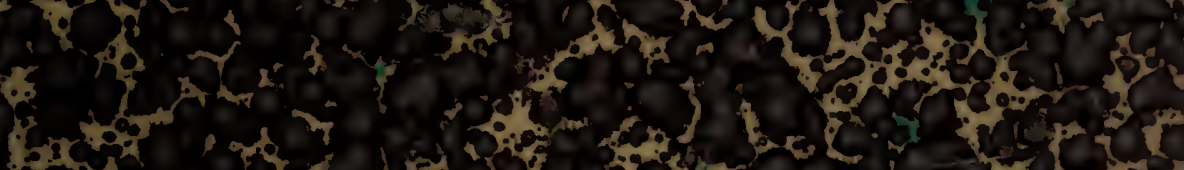

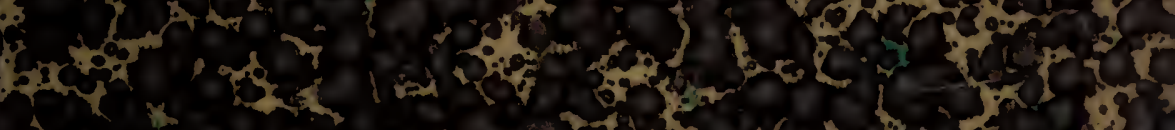

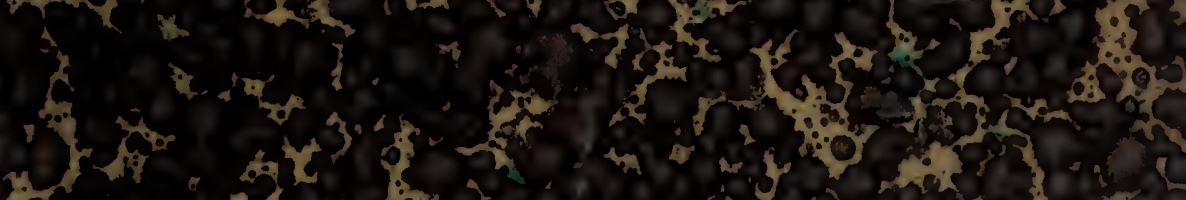

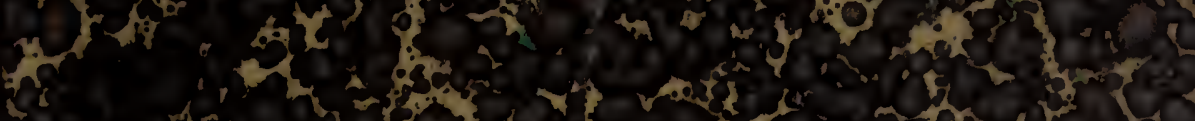

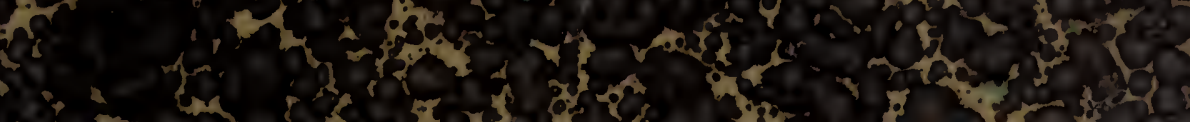

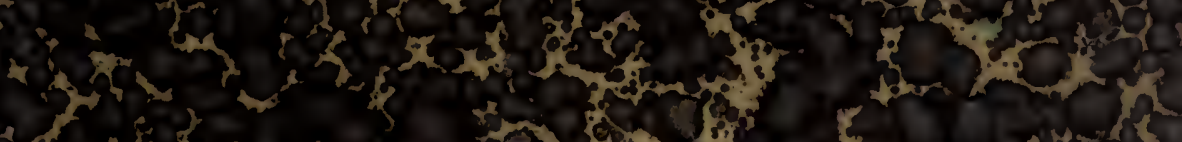
I.

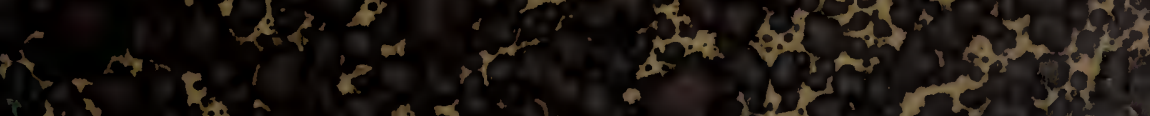

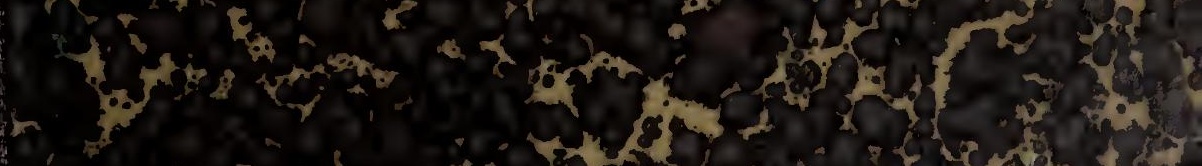

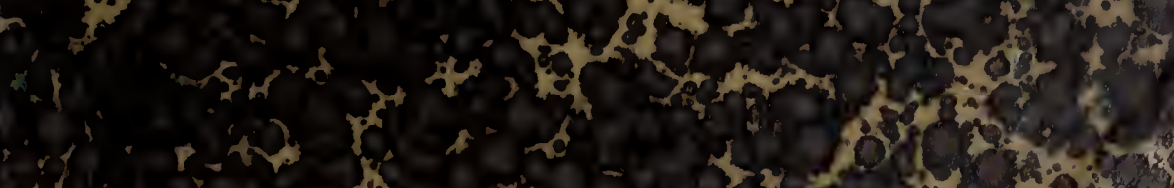
1 D.t.

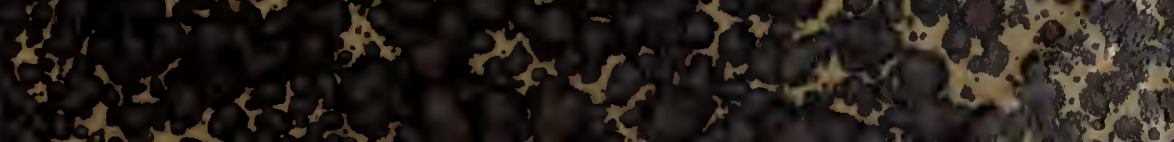



20.3. $8 \sin ^{2}, 49$ 3f atis (3) $\rightarrow 10$ octint.

tI. $2 x^{2}+3 x^{5}$

UNIVERSITY OF ILLINOIS

LIBRARY

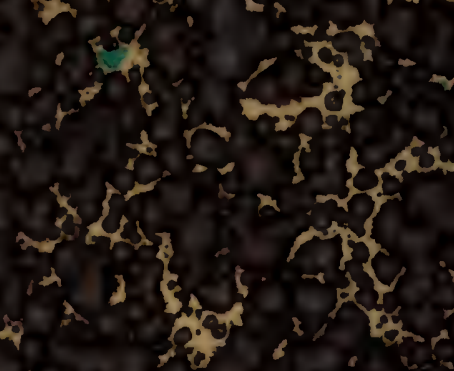

ENOA 

Tieldiana 

govergecal serues U.3 

Field Columbian Museum

Publication 54.

Zoological Series. Vol. ili, No. 3.

\section{LIST. OF MAMMALS}

OBTAINED BY

\section{THADDEUS SURBER,}

COLLECTOR FOR THE MUSEUM,

IN THE

\section{PROVINCES OF NEW BRUNSWICK AND QUEBEC, CANADA.}

BY

D. G. Elliot, F.R.S.E.

Curator of Department.

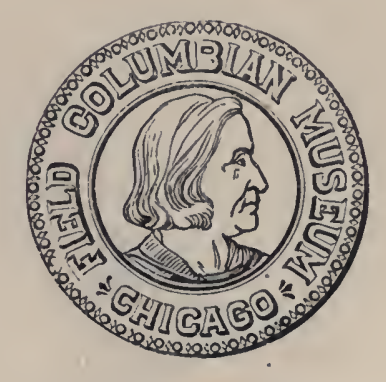

Cincago, U. S. A. March, Igor. 



\title{
LIST OF MAMMALS
}

OBTAINED BY

\author{
MR. THADDEUS SURBER,
}

Official Collector of the Museum

In the Proninces of New Brunswick and Quebec, Canada,

IN THE SUMMER OF IgOO.

By D. G. ELLIOT, F.R.S.E.

The following named species were procured by Mr. Surber in New Brunswick and Quebec at eight different points in the two Provinces. He began to collect at Dalhousie, on the Bay of Chaleur, then went to Metapedia, Salmon Lake, and Riviere du Loup. Here he crossed the St. Lawrence to Murray Bay, and from that place went to. Lakes Edward and Ecarte. From this locality he proceeded to Tadousac via Lake St. John, and then, passing again to the south shore, he returned to Metapedia and ascended the Restigouche River to the mouth of Two Brooks. Here he ascended to the higher plateau to a small lake, and a stream called Grog Brook, situated on the divide between the Upsalquitch and Restigouche Rivers. At this place, during his absence, the camp was burned with the loss of all the specimens he had collected since leaving Metapedia. This misfortune compelled him to return. Up to the month of August the season had been very wet, making collecting difficult and unpleasant. At Tadousac not a single mammal was taken and no signs of any noticed, and it would appear that the place had been abandoned by four-footed creatures. A week was passed there in a vain search. I have added Mr. Surber's notes, and they will be found attached to each species over his initials.

\section{ORDER I. UNGULATA.}

FAM. CERVIDÆ.

I. Rangifer caribou.

Rangifer caribou. Gmel. Syst. Nat., I, I788, p. 177.

No examples obtained.

"Caribou are somewhat common back to the westward of Lake Edward and I saw numerous tracks of this species between Lake Edward and Lake Ecarte. They are numerous 
also to the northward of Salmon Lake, being occasionally seen at the border of that body of water. However, it is in the region about Grog Brook that I saw most signs of their presence, and it was no trouble to find a dozen fresh tracks any morning of my stay there, both on the barrens and in the forest. Several deeply worn game trails cross Grog Brook and the barrens on either side, and during my stay neither the moose nor caribou seemed to use them, it being then probably too late in the season. It is no trouble to get a caribou in that section.

"I was told however by many guides that the best section of country for this species during September is the region just north of the Patapedia River, reached by portage road from Amqui, a small place on the Intercolonial Railway." (T. S.)

\section{Alces americanus.}

Alces americanus. Jard. Nat. Libr., I835, Mamm., p. I25.

No specimens obtained.

In Quebec on the north shore of the St. Lawrence the moose is very rarely met with. The species was nearly exterminated in many localities, but a law prohibiting any one to shoot a moose for five years gave the animals a chance to increase their numbers, and they began to appear again in their old haunts. On the south side of the river, especially in New Brunswick, they are not uncommon.

"Moose are found sparingly throughout the region visited, being common only in the vicinity of Two Brooks on the Restigouche and further up the Restigouche and Patapedia Rivers. While at Salmon Lake, early one foggy morning I got quite close to two moose, but they made off in a hurry on seeing me. During my stay at Dalhousie a bull moose was seen two or three times in an old meadow within the town limits, very early in the mornings on each occasion. The Restigouche region is the best moose country in Eastern Canada, thanks to a wise law, and before I left there the latter part of September I heard of several sportsmen who had secured their moose. One was killed within the limits of the town of Riviere du Loup in September. Moose are rather scarce in the region about Lake Edward and on my canoe trip to Lake Ecarte I saw but one track. While camped on the head of Grog Brook, New Brunswick, I trailed one up one day, but the red squirrels, which seemed that day unusually noisy, warned it in time and I only caught a glimpse of it as it 
rushed away. There are many moose in that section, as I daily saw fresh tracks, some of large size."

(T. S.)

\section{Odocoileus americanus.}

Odocoileus americanus. Erxl. Syst. Regn. Anim., I777, p. 312.

No specimens procured.

"Red deer are not found at all in most of the region covered by the writer, and I saw tracks of them only on the high land about Grog Brook and one track on Dalhousie Mountain. I am told they have only made their appearance in Restigouche County, New Brunswick, within the past fifteen years, being unknown previous to that. Back some distance from Riviere du Loup toward the Madawaska region they are said to be plentiful. Mr. Rowley tells me they have been unknown above Lake Edward till about a year ago one was seen on the Vermillion River (the outlet of Lake Ecarte). The winters at Lake Edward, from its I, 200 feet elevation, are too severe for this deer."

\section{ORDER RODENTIA.}

\section{FAM. SCIURIDA.}

\section{Sciurus hudsonius.}

Sciurus hudsonius. Erxl. Mamm., I777, p. 416.

Specimens from Dalhousie, New Brunswick, Murray Bay and Lake Edward, Quebec.

These examples were taken in June, July and August. The June have the broad, reddish dorsal stripe and dark hands and feet; those of the two other months are without dorsal stripe and with buff colored hands and feet. The tails vary in the center from a rich red of the July specimen to a mixed red and buff, the latter on the tips of the hairs.

"Red squirrels were common at all the places visited, except in the region about Murray Bay and at Riviere du Loup. I saw none at all at the latter place, but at Murray Bay well up toward the summit of the mountain near the village I saw several. Near my camp at Grog Brook, between the Restigouche and Upsalquitch Rivers in northern New Brunswick, they were extremely abundant and made a great noise in the brush of a clear frosty morning; in fact, they are a regular nuisance to the big game hunter in that section, and scared a big moose away 
from the writer one morning when almost within rifle shot. Near Lake Edward they are also abundant."

5. Tamias striatus lysteri.

Tamias striatus lysteri. Rich. Faun. Bor. Amer., I829, I, p. I 8 I, pl. I 5 .

Fourteen specimens, I from Riviere du Loup, I 3 from Murray Bay, Province of Quebec.

Not uncommon at Murray Bay, but none was procured at Lake Edward nor in the other places visited except Riviere du Loup.

"On the mountain side near Murray Bay I found this species very common, taking, however, but I3 specimens during my stay. On the south shore of the St. Lawrence at Riviere du Loup I saw two but secured only I specimen, while at Tadousac this was the only species of mammal I saw, but I saw only one there and that I failed to secure. While at Lake Edward I am pretty sure I heard one of this species one day, and afterwards trapped the place thoroughly but without success. Mr. R. Rowley tells me it is found at Lake Edward but is rare. At Grog Brook 2 specimens were secured, but lost in the fire which destroyed my camp. They are not at all common in northern New Brunswick, from all I could learn, and I failed to get any at Dalhousie, though I was told they were found there." (T. S.)

\section{Arctomys monax canadensis.}

Arctomys canadensis. Erxl. Syst. Anim., I777, p. 363.

Seven specimens from Murray Bay, Quebec.

This variety of the common woodchuck, $A$. monax, was quite numerous at Murray Bay. It is smaller than its southern relative, and much more golden on the under parts, while the head is not so dark. Like $A$. monax, individuals vary considerably in color, some being much more hoary above than others, and the color of the hands and feet vary from black to chestnut. The skulls differ mainly in size.

Measurements of adults are: Total length, 5 10-562; tail vertebræ, I08-i 40; hind foot, 74-78.

"Woodchucks are common all through the section visited, except in the country about Lake Edward and the dense forest between the Restigouche and Upsalquitch Rivers. They are particularly abundant on the hills about Murray Bay, where they find abundant food in the grass lands there, and I secured 7 
specimens of different ages. A 'siffleur's' den is about as bad smelling as a fox's, which it resembles very closely, but I never noticed it elsewhere than at Murray Bay. I saw several woodchucks from the car window while en route to Lake St. John, near Chambord Junction, and from the character of the country presume they are common there, but at Tadousac, in country exactly similar to that about Murray Bay, they were apparently not at all common."

(T. S.)

\section{SUB-FAM. PTEROMYINE.}

7. Sciuropterus sabrinus.

Sciuropterus sabrinus. Shaw, Gen. Zool., I, I8or, p. I57.

Lake Edward, Quebec.

Flying squirrels were not at all common. In fact, Lake Edward was the only locality in which any were seen.

"Near the Laurentides House, Lake Edward, I trapped the only specimen of flying squirrel taken on the trip, taking it in a clump of balsam trees on a side hill. Mr. Robert Rowley, the proprietor of the hotel there, tells me it is a rare mammal in that section. At Metapedia, I was told of some flying squirrels having been taken a few years ago near the clubhouse belonging to the Restigouche Salmon Club. While up the Restigouche, my guide and myself searched everywhere for this mammal, but in vain. I could not hear of it at the other places visited, so it must be rare."

(T. S.)

\section{FAM. CASTORIDA.}

8. Castor canadensis.

Castor canadensis. Kuhl, Brit. Zool., r820, p. 64;

"I was shown a fresh beaver dam near Lake Ecarte, about 20 miles from Lake Edward, which was, during the time of my visit, the home of a small colony of beavers, but of course they were carefully protected. Mr. Rowley told me of another colony which he is carefully watching near Lake Edward. The only other place I saw any signs of beaver was at Grog Brook, about a mile from where I camped, though therewere plenty of old cuttings about Two Brooks Lake. They are becoming very scarce in the region visited, but are now rigidly protected by law, and let us hope this may save what few remain."

(T. S.) 
FAM. MURID厓.

\section{Mus norwegicus.}

Mus norwegicus. Erxl. Syst. Reg. Anim., I777, p. 38 I.

Mus decumanus. Pall. Glir., I778, p. 9 I.

One specimen taken at Murray Bay, Province of Quebec.

"House rats are found at all the points visited, except those remote from civilization. One specimen of rather peculiar color was taken at Murray Bay."

\section{Io. Peromyscus canadensis.}

Peromyscus canadensis. Miller, Proc. Biol. Soc. Wash., I893, p. 55 .

Twenty specimens from Salmon Lake and Riviere du Loup, New Brunswick, and Murray Bay, Quebec.

These examples are evidently true canadensis, Miller. No Peromyscus were taken at Lake Edward, so I am unable to make any comparisons with abietorum, Bangs. Murray Bay being but a comparatively short distance from Lake Edward and on same latitude, should produce abietorum, but all the specimens are canadensis. It is true that.some of the younger examples answer very well to Bangs' description, and gives rise to the suspicion that abietorum may only be immature canadensis, and the total absence of any adults differing from canadensis in my series strengthens the idea.

"It seems strange no specimens of white-footed mice were secured in upper New Brunswick, the nearest point being Salmon Lake, Province of Quebec, on the Metapedia River, where one was taken. They were fairly common about Riviere du Loup, where I secured several specimens, and were al'so fairly common at Murray Bay, which was the only point north of the St. Lawrence where I took specimens. I find this mouse lives almost exclusively in the hardwood forests, and there being only small widely separated tracts of such timber north of the St. Lawrence may, in some manner, account for its absence, but this will not account for my not finding it at Dalhousie, where there is plenty of hardwood."

(T. S.)

II. Evotomys gapperi.

Evotomys gapperi. Vigors Zool. Journ., v, I830, p. 204, pl. ix.

Twenty-six examples from Dalhousie, Salmon Lake, Metapedia, Upper Restigouche River and Lake Edward, Provinces of New Brunswick and Quebec. 
In this series, so far as their appearance is concerned, there are two very distinct styles of Evotomys. One is a light colored, rather long and loose haired animal; the other short haired, smooth and dark colored. Many species of North American Mammals have been described that possessed far less claims for distinctive rank so far as texture and color of fur is concerned. The dark colored form has been supposed by Mr. Bangs to be the only one represented at Lake Edward and to be true gapperi (Proc. Biol. Soc. Wash., x, I896, p. 49). The type of gapperi came from Lake Simcoe, Ontario, Canada, and the description indicates an animal of the light colored style. I have no specimens from Lake Simcoe to compare with my present series, the nearest specimen to that locality before me being from Trout Creek, to the north of Lake Simcoe and not far from Lake Nipissing. This is of the light variety and in outward appearance entirely unlike the dark colored specimens, but exactly resembling the light examples in my series. It is therefore probable, judging from the description, that the dark colored form is not typical gapperi, with buffy-ochraceous sides, brownish tail and silvery gray feet, for none of these characters apply to it,'since the sides are dark, more or less lined with buff; the hands and feet brownish black, with tufts of white hairs concealing the nails; and the tail brownish black above, grayish beneath and tipped with black, causing the animal to be quite different so far as the coloring is concerned. Specimens of both styles were collected in the months of June, July, August and September, and these exhibited no changes in their coloration, each one preserving its distinctive hues, and the young resembling the adults. Now why should there not be two species, when they are so entirely different in appearance and, so far as known, show no evidence of intergrading. Simply because both are found in the same localities, and it is not probable that two so closely allied forms of the same genus could inhabit the same localities and remain distinct. In all the places, from Dalhousie to Lake Edward, both styles were obtained, except on the upper waters of the Restigouche, where only the dark form was procured, but it does not follow that the light form is not also to be found there. This series presents a very puzzling problem, for the color of the pelage in neither style presents a seasonal phase, else they would likely resemble each other; nor one resulting from age, as the young and the adults are exactly alike. The skulls of both styles exhibit no differences whatever that would 
indicate two species. It is desirable to obtain specimens from Lake Simcoe, the type locality, for comparison, and these, unfortunately, I do not possess, but I am satisfied, judging from the present series and the Trout Creek specimen, that both the light and dark forms will also be found there. At Murray Bay, although every effort was made for over two weeks to obtain specimens of Evotomy, none were taken. The following is a description of the dark style: Specimen from Lake Edward, No. 724, taken August 5, Igoo. Head and upper parts very dark rich chestnut; sides dark, thickly lined with buff; sides of nose yellowish; cheeks and under parts silvery white, the dark base of the hairs showing through. Hands and feet brownish black, nails hidden by tufts of white hairs. Tail brownish black above, grayish beneath, tip black; ears like the back. Measurements: Total length, I $46 \mathrm{~mm}$; t tail vertebræ, 43 ; hind foot, 20 . This problem requires further investigation. It will be noticed that the above description does not at all indicate typical gapperi. Mr. Bailey does not speak of the dark form here described, in his paper on Evotomys, ${ }^{*}$ and he did not have any specimens from Lake Simcoe.

"I took the red-backed vole as low down as 25 feet above sea level at Dalhousie, New Brunswick, finding them among the rocks and logs of Dalhousie Mountain. 'At Lake Edward they. were also fairly common, living under old logs, their runways extending in every direction through the deep moss on the steeper hillsides; in fact, this vole, in my opinion, lives almost wholly on sloping ground, for I've never taken any on level ground anywhere. I searched for it, but without success, at Murray Bay, and do not believe it is found there, while at Riviere du Loup only one imperfect specimen was taken."

12. Microtus pennsylvanicus.

Microtus pennsylvanicus. Ord. Guthr. Geog., I8 15 , 2d ed., p. 292.

Fifteen specimens from Dalhousie, Restigouche River, Murray Bay and Lake Edward.

This species appeared to be more common in New Brunswick than in Quebec, as only 4 specimens were procured at Murray Bay and I at Lake Edward. M. chrotorrhinus, Miller, was not obtained.

"Meadow voles were apparently more common in a wet meadow at Dalhousie, New Brunswick, than elsewhere, but I 
got only 8 specimens, there. At Two Brooks I secured 2 specimens in a sphagnum bed by the brook and at Grog Brook two more were taken on the barrens, also among the deep reddish moss. At Murray Bay only 4 specimens were taken, all being secured in a small sphagnum swamp, where they were apparently common, but luck seemed against my securing many specimens. Mr. Ferguson told me they. were found at Metapedia, though I searched there for it in vain."

\section{Microtus fontigenus.}

Microtus fontigenus. Bangs, Proc. Biol. Soc. Wash., I896, p. 48 .

Three examples of this vole were obtained at Lake Edward.

"I secured Bangs' Vole in only one place near Lake Edward, a sphagnum swamp by the railroad only a short distance south of the Laurentide's House, and their runways were quite numerous, but probably owing to the unusually wet weather then prevailing, they were not much frequented. I trapped persistently, but secured only 4 specimens. From what I learned while at Lake Edward, Mr. Bangs got his specimens about a mile north of the station, but I could not catch any specimens at all there during five days' trapping."

(T. S.)

14. Synaptomys fatuus.

Synaptomys fatuus. Bangs, Proc. Biol. Soc. Wash., i 896,p.47. Three specimens of this scarce species were procured at Lake Edward.

" Bangs' Lemming Vole must be a rather rare species even at Lake Edward, for I spent nearly three weeks getting 3 specimens. The first one was taken from a Microtus runway in the sphagnum swamp near the Laurentide's House (where I secured M. fontigenus), the second specimen was taken well up a steep side hill in a trap set in a Evotomys runway under a log, while the third one was taken among the rocks on a rather barren hill in front of the station at Lake Edward, where there was very little cover except dead huckleberry bushes."

\section{Fiber zibethicus.}

Fiber zibethicus. Linn. Syst. Nat., I, I 766, p. 79.

"I took four muskrats, two at Lake Edward and two at Grog Brook, but unfortunately the former were lost through the express company and the latter were destroyed in the fire at my 
Grog Brook camp. Muskrats are compon about Lake Edward; in fact, one of the tributary rivers of that lake is named Riviere aux Rats, from the immense number of these mammals at one time found there, but it is now rather more noted as a brook trout stream. I tried my best to secure muskrats at Dalhousie, but was foiled, for they are scarce there. From all I could learn they were less common at Riviere du Loup and Murray Bay than elsewhere. The 4 specimens secured appeared to me identically like specimens taken in West Virginia, though perhaps slightly darker in color."

\section{FAM. ZAPODIDE.}

I6. Zapus hudsonius.

Zapus hudsonius. Zimm. Geog. Gesch. Mens. u. vierfuss. Thiere., I780, i I, p. 358.

Two examples from Murray Bay, Quebec.

The jumping mice seem to be scarce throughout all the region visited by Mr. Surber. One of the specimens secured was taken in a trap, the other was caught and brought in by a house cat. Z. insignis, taken by Mr. Bangs at Lake Edward, although diligently sought for both at the lake and at Tadousac and the Restigouche River, was not procured.

"Murray Bay was the only place at which I secured the jumping mouse. I took one in a trap set by a little brook on the mountain side and a few days later a boy brought me one which had been taken from a cat. Mr. Maltais of Murray Bay informed me he killed many every year during hay harvest, but he may not be able to distinguish between it and a Peromyscus. It is a hard species to trap."

FAM. ERETHIZONIDE.

I7. Erethizon dorsatus.

Erethizon dorsatus. Linn. Syst. Nat., I758, p. 57.

No specimens were obtained. During hunting trips extending over many years on both sides of the St. Lawrence, I have never met a porcupine.

"At Salmon Lake on the Metapedia River I saw a tame porcupine and was told they were fairly common in the country to the northward of that place. At Lake Edward and the region thereabouts they are still found, but are becoming scarce. The only place I saw any signs of their work was on the portage 
road leading from the Restigouche River into Two Brooks Lake and in the country about Grog Brook. Porcupines are evidently becoming scarce about the more thickly settled sections of country visited."

\section{FAM. LEPORIDAE.}

18. Lepus americanus.

Lepus americanus. Erxl. Syst. Regn. Anim., I777, p. 330.

"The northern hare was fairly common all through the region visited, but was abundant only in the region about Lake Edward. It is found only in the heavily timbered region, where its runways are plainly marked in the deep moss, but I saw one at Dalhousie in an old field some distance from the timber. I was told at Murray Bay that they were not at all common near there. I caught several at Lake Edward, all but two were half grown young, and the two skins preserved were lost in transit somewhere between Quebec and Buffalo, N. Y. Owing to the dense cover they inhabit, hares are seldom seen, consequently few are shot; what specimens I took were captured in steel traps set in their runways."

(T. S.)

\section{ORDER CARNIVORA.}

FAM. MUSTELIDÆ.

19. Mephitis mephitica.

Mephitis mephitica. Shaw, Mus. Lever., I792, p. I7I.

Two specimens from Murray Bay, Quebec.

Skunks were exceedingly numerous at Murray Bay and in the surrounding district. Like those collected by Mr. Bangs at Lake Edward, the skulls of these examples lack the median palatal spine, although skulls of Mephitis from the neighboring Province of Ontario possess this spine. It is a large animal and apparently consistent in its markings in Canada.

"A very large $q$ skunk was taken at the village of Pointe á Pic, where it had taken up its residence under one of the cottages. Another one stumbled into a trap I had set under an old barn up the side of the mountain at Murray Bay. This was a rather nice $\delta$, and both specimens being extremely fat. Skunks are found near Lake Edward, but are very rare, and they are also found in the Restigouche and Metapedia valleys near Metapedia, as well as near Salmon Lake." 
20. Mustela americana.

Mustela americana. Turton, Syst. Nat., I, I806, p. Io6.

"The pine marten is found in the vicinity of Lake Edward and Salmon Lake in fair numbers, many skins being taken each winter. On the portage road leading from the Restigouche to Two Brooks Lake I saw many deadfalls built for catching this mammal, and at Grog Brook my guide took 2 fine specimens in steel traps set near the entrails of a caribou, taking one the $\mathrm{I}_{4}$ th, the other the 2oth of September. The skull of one of these specimens was saved from the fire in fairly good condition, but in some manner was lost on the portage coming out, and though I went back to search, failed to find it. On the trip back through the chain of lakes between Lake Edward and Lake Ecarte I saw many deadfalls built for taking this mammal, and it may yet be considered common in that region and on the Upper Restigouche."

(T. S.)

21. Putorius vison.

Putorius vison. Briss. Regn. Animal, r756, p. 246.

Two examples from Rat River, Lake Edward.

"Minks are scarce in the immediate vicinity of civilization throughout the section visited, but I heard of them at every place visited, though they were apparently less common about Murray Bay. They are more abundant near Lake Edward than elsewhere, and I secured a very fine $\delta$ there and a little later a $q$ at Rat River. Also took one at Grog Brook, but it was destroyed with the other specimens secured there." (T. S.)

22. Mustela pennanti.

Mustela pennanti. Erxl., Syst. Regn. Anim., I777, p. 470.

"The only place at which I heard of the fisher was at Lake Edward, where they are becoming scarce, however. Mr. Rowley gets a few skins each winter from trappers, who get them in the wild region to the westward of that place." $\quad$ (T. S.)

23. Lutra canadensis.

Lutra canadensis. Kerr, Linn. Anim. King., r777, p. 448.

"Otters are still found at Salmon Lake, and at the little lake near my camp at Grog Brook I saw a fresh slide, but failed to trap any. In August, I shot an otter, the only one I saw, in the Vermillion River (outlet of Lake Ecarte), but it was lost in the rapids of that fine trout stream. Mr. Rowley told me otters 
were common in some of the smaller lakes west of Lake Edward, but I believe it is more or less rare in most of the section visited."

(T. S.)

24. Felis canadensis.

Felis canadensis. Desm. Mamm., I820, p. 224.

No specimens taken.

"On one of the portages between Lake Edward and Lake Ecarte, near Lake Algonquin, I saw the tracks of a 'Loup cervier,' and, one night while in camp at Grog Brook, one set up an unearthly screech in a cedar thicket quite near the tent. At Salmon Lake I saw a skin of one taken in the vicinity, where it is said to be fairly common. Many are yet found up the Restigouche River, where they find abundant food in the parks of Canada grouse, so numerous there." (T. S.)

25. Canis occidentalis.

Canis occidentalis.' Rich. Faun. Bor. Amer., I829, p. 60.

No specimens secured.

"Wolves are now rare throughout the region, but a few are still found near Lake Edward and Salmon Lake, where they hang around the caribou herds in winter. I was told they are plentiful in the wild, unexplored Shicksebocks Mountains of the Gaspé Peninsula."

(T. S.)

26. Vulpes pennsylvanica.

Vulpes pennsylvanica. Bodd. Elench., I, I784, p. 96.

No examples secured.

"Red foxes are rather common about Metapedia, Salmon Lake, Riviere du Loup and Murray Bay, but are rare at Lake Edward. I have never yet succeeded in trapping a fox and all my efforts to get a specimen failed."

(T. S.)

FAM. URSID在.

27. Ursus americanus.

Ursus americanus. Pall. Spicil. Zool. fasc. xiv, I780, pp. 5-7.

No specimens obtained.

Black bear are found in limited numbers throughout the forest region visited by Mr. Surber, and some are secured yearly by trappers and hunters.

"The only place I saw any signs of bear was at Grog Brook, where the fresh foot-prints of a medium size one was seen one 
day on the barrens. They are still found in limited numbers near Salmon Lake and Lake Edward, but it is a rather rare species in the whole region, unless it is far up the Restigouche River.

"I made frequent inquiries about the wolverine (Gulo), but could not hear of it anywhere, so it must be a very rare animal indeed."

\section{ORDER INSECTIVORA.}

\section{FAM. SORICIDA.}

28. Sorex personatus.

Sorex personatus. Geoff. St. Hil. Mem. du Mus. Paris, I827, $\mathrm{xv}$, pp. I22-I 25.

Five specimens from Dalhousie and Lake Edward.

"I met with this shrew only at Dalhousie, New Brunswick, and at Lake Edward and Lake Ecarte in Quebec, and it was apparently more common near Lake Edward than elsewhere. It is apparently as common on side hills among moss-covered logs as it is in the deep, moist sphagnum of old swamps."

\section{Sorex fumeus.}

Sorex fumeus. Miller, N. Am. Faun., No. Io, I895, p. 50.

Two specimens from Restigouche River and Riviere du Loup.

"Specimens of this interesting shrew were obtained at only two places, Riviere du Loup on the St. Lawrence and Two Brooks on the Restigouche, a specimen at each place, so it must be a rare mammal. Both wẹre taken by little streams under old moss-covered logs deep in the spruce woods."

30. Blarina brevicauda.

Blarina brevicauda. Say in Long's Exp. Rocky Mts., I, I823, p. I64.

Fifteen examples from Dalhousie, Restigouche River, Metapedia, Riviere du. Loup, Murray Bay and Lake Edward, Provinces of New Brunswick and Quebec. This shrew was very common in all places visited where any specimens of mammals were taken.

"I found short-tailed shrews most common in some hardwood forest at Riviere du Loup, but also took specimens at Lake Edward, Murray Bay, Metapedia and Two Brooks and Dal- 
Mar. igot. Mammals from N. Bruns. and Que.-Elliot.

housie, New Brunsivick. Apparently it is fairly common throughout the region."

\section{FAM. TALPID $Æ$.}

3r. Condylura cristata.

Condylura cristata. Linn. Syst. Nat., I758, p. 53.

No specimens procured.

"Both Prof. Elliot and myself searched for this mole at Murray Bay, but without success, and Mr. Maltais showed me where he had some time previously seen its hill, but none could be found during my visit. I searched for it everywhere I visited, but could not find any signs of its presence, though it undoubtedly occurs all through the region."

(T. S.) 





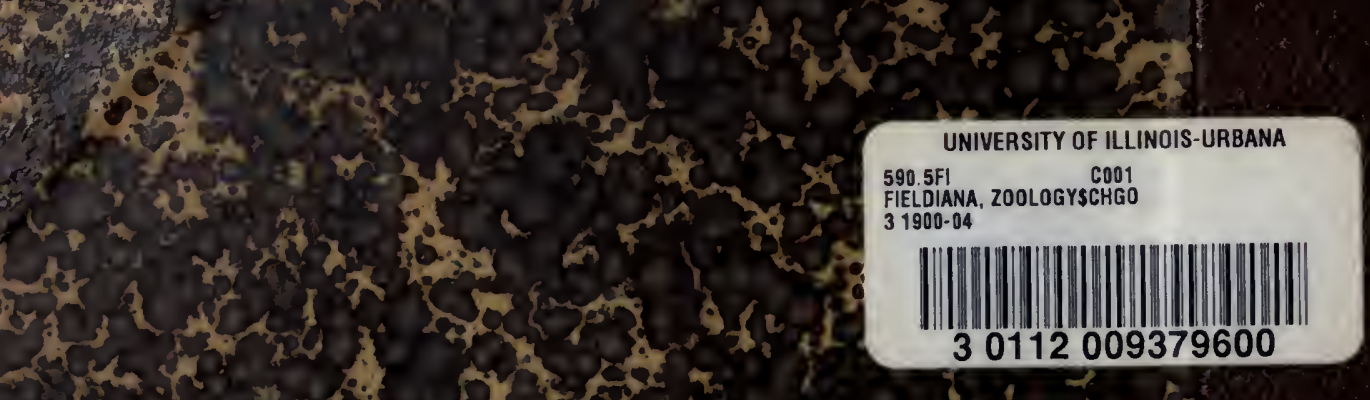

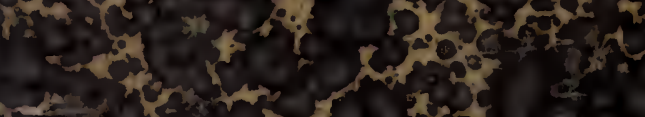

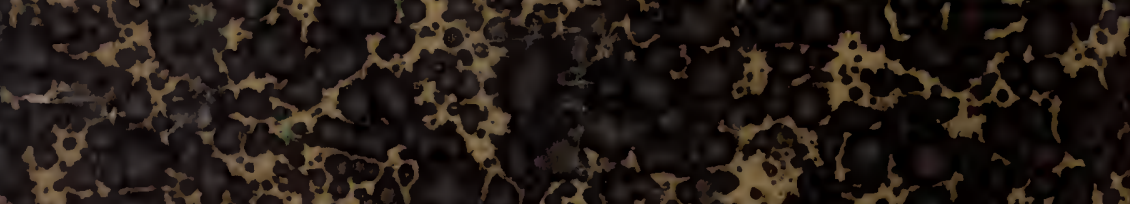

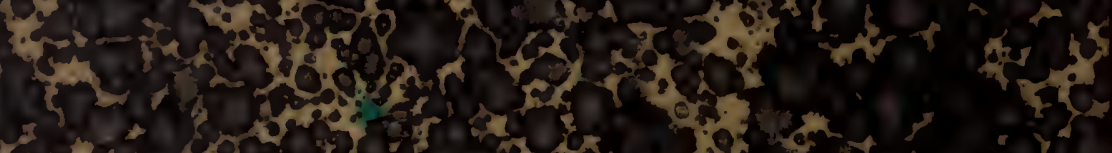
(1) D. 18 o - bom 5.250

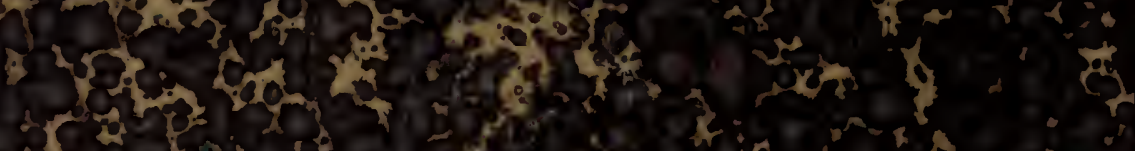
2. 3 -

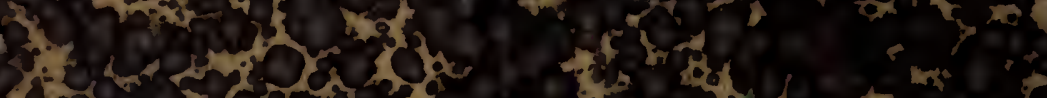

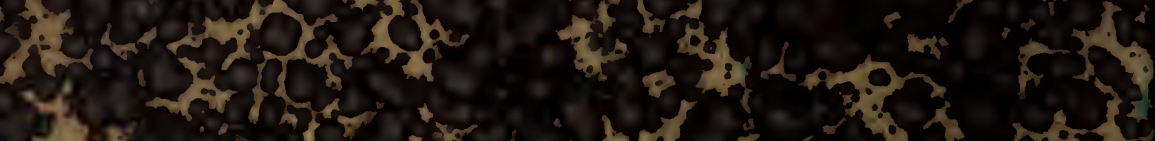
Go 30 . 3. 30 .

- $40.6 \%$

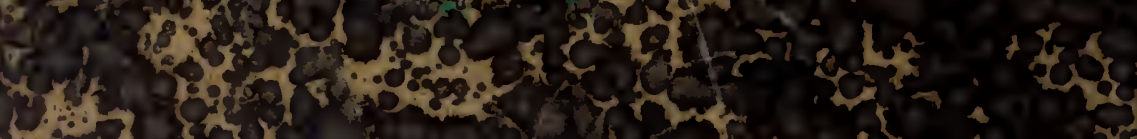

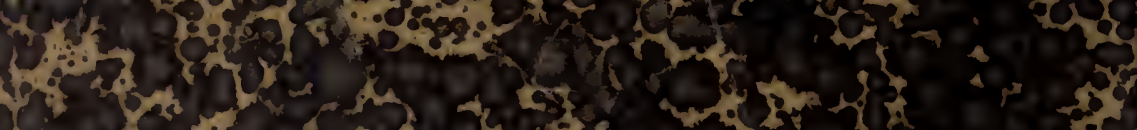

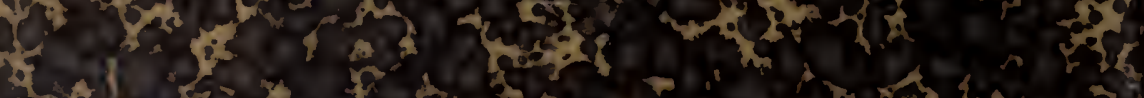
it it to t

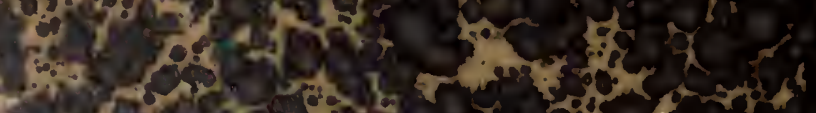

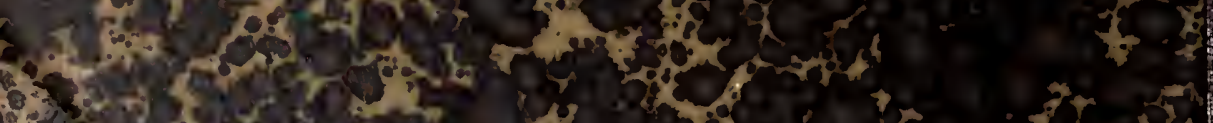

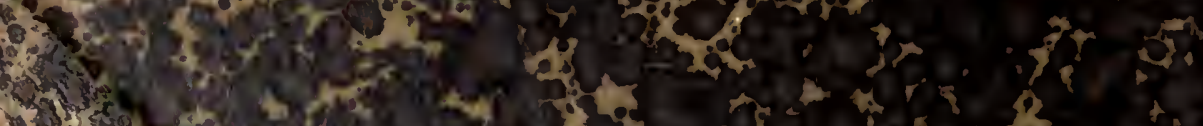
1.

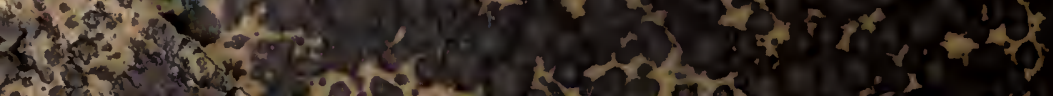

